\title{
Pemahaman siswa SMA tentang keanekaragaman genetik berdasarkan eksperimen DNA mitokondria Cuora amboinensis Sumatera
}

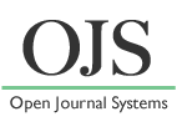

\author{
Yulinda Fitriani*, Aceng Ruyani, Bhakti Karyadi \\ Pascasarjana Pendidikan IPA FKIP Universitas Bengkulu, Bengkulu \\ *Email: yulindayuwan@gmail.com
}

\begin{abstract}
ABSTRAK
Indonesia kaya akan keanekaragaman hayati, salah satunya adalah Coura amboinensis yang terletak di Aceh, Bengkulu dan Enggano. Penelitian ini bertujuan untuk merancang media pembelajaran audio visual yang dikembangkan dari hubungan kekerabatan Coura amboinensis dari Aceh, Bengkulu, Enggano menggunakan DNA mitokondria untuk digunakan sebagai referensi ketika mengisi Lembar Diskusi Siswa untuk mengukur kemampuan siswa kelas 10 Madrasah Aliyah Ja -alhaq Bengkulu untuk materi keragaman genetik. Tipe Penelitian ini merupakan penelitian deskriptif yang dianalisis pengembangannya. Hasil penelitian menunjukkan desain media dengan merakit kegiatan eksperimen DNA Cuora amboinensis menjadi video pembelajaran melalui tahapan analisis kurikulum, validasi ahli membentuk media audio visual yang mampu menarik perhatian siswa saat pembelajaran karena video terdiri dari video pengantar berasal dari youtube, isi dari seri dan penutup proses eksperimental. Hasil penelitian media ini menyimpulkan bahwa penggunaan media pengajaran audio visual berhasil membuat siswa mudah memahami materi keragaman genetik.
\end{abstract}

Kata kunci: Pemahaman siswa; keanekaragaman genetik; eksperimen DNA; Cuora amboinensis.

\section{PENDAHULUAN}

Indonesia terletak di daerah tropik sehingga memiliki keanekaragaman hayati yang tinggi, tingginya keanekaragaman di Indonesia terlihat dari berbagai macam mahluk hidup baik flora maupun fauna. Iverson (1992) menyebutkan bahwa penyebaran spesies ini di Indonesia cukup luas seperti Pulau Sumatra, Jawa, Kalimantan.

Makhluk hidup memiliki ciri dan tempat hidup yang berbeda. Melalui pengamatan, kita dapat membedakan jenis-jenis makhluk hidup. Perbedaan makhluk hidup secara alami diperoleh berdasarkan bentuk, ukuran, warna, tempat hidup, tingkah laku, cara berkembang biak, dan jenis makanannya. Faktor yang menyebabkan perbedaan adalah keanekaragaman. Keanekaragaman disebabkan oleh dua faktor yaitu genetik dan lingkungan.

Keanekaragaman kura-kura secara morfologi maupun secara genetik merupakan sumber belajar bagi siswa Sekolah Menengah Atas. Pembelajaran Biologi di SMA memuat materi tentang Keanekaragaman Hayati, sehinga informasi tentang keanekaragaman genetic kurakura batok (Cuora amboinensis) dapat dijadikan media ajar dalam proses pembelajaran di kelas, karena hal tersebut berhubungan langsung dengan media ajar keanekaragaman Hayati dan Genetik yang terdapat pada kurikulum Sekolah pada tingkat Sekolah Menengah Atas (SMA). Berdasarkan pengalaman peneliti yang mengajar mata pelajaran Biologi, bahwa mata pelajaran Biologi khusunya materi yang berhubungan dengan genetik relatif sulit di pahami siswa, karena materi ini objek-objeknya mikroskopik dan diluar pengalaman sisswa sehari-hari sehingga terasa abstrak bagi siswa. Siswa akan jauh lebih mudah memahami jika materi yang diajarkan dalam bentuk yang kongkrit. Untuk itu sangat diperlukan inovasi dalam pembelajaran salah satunya melalui pengembangan media ajar dari hasil penilitian.

Inovasi pembelajaran yang dipilih mengikuti kemajuan ilmu pengetahuan dan teknologi khususnya teknologi informasi 
sehingga strategi pembelajaran dapat disusun untuk mencapai tujuan pembelajaran, membuat proses pembelajaran lebih menarik dan diharapkan lebih mudah di pahami siswa khususnya pada materi keanekaragaman genetik yang begitu abstrak bagi siswa menjadi lebih kongkrit. Tahap operasi kongkret dapat ditandai dengan adanya sistem operasi berdasarkan apaapa yang kelihatan nyata (Math, 2017).

Bentuk media teknologi informasi yang dapat digunakan yaitu berupa audio visual yang menggabungkan dua jenis media langsung yaitu audio (mendengar) dan visual (melihat) sehingga siswa dapat melihat objek secara normal.

Hasil penelitian yang didapatkan diimplementasikan dalam media audio visual, dan diharapkan dapat memberikan informasi tentang perbedaan dan hubungan kedekatan kekerabatan C.amboinensis, pada 3 daerah tersebut dan dapat menjadi usaha konservasi awal terhadap kura-kura yang terdapat di Sumatera khususnya Aceh, Bengkulu, dan Pulau Enggano.

\section{METODE PENELITIAN}

Penelitian diawali dengan melakukan analisis materi pembelajaran sains berdasarkan kurikulum tiga belas (K-13), dilanjutkan dengan penyusunan konsep, penentuan gambar/animasi, penentuan efek suara sehingga sampai terbentuk menjadi audio visual. Media audio visual sebelum di uji cobakan diawali dengan validasi yang dilakukan oleh beberapa tim ahli yaitu ahli media, ahli teknologi, ahli isi dan ahli pembelajaran. Analisa data uji validasi ahli menggunakan Intracorelation class coefisien (ICC) dimaksudkan untuk membandingkan kekonsistenan dari beberapa penilai.

Menurut Winarni (2012) validasi dilakukan untuk mendapatkan pertimbangan judgement berdasarkan pertimbangan dan analisis panelis. Validasi ini bertujuan untuk memperoleh pengakuan atau pengesahan atas layak atau tidaknya video pembelajaran yang telah dibuat agar dapat digunakan sebagai media belajar.

Pemahaman siswa terhadap media audio visual yang dibuat diukur melalui lembar diskusi siswa. Lembar diskusi siswa yang terdiri dari 5 dimensi pemahaman : memberikan penjelasan sederhana, membangun kemampuan dasar, menyimpulkan, memberikan penjelasan lebih lanjut, mengatur strategi dan taktik akan dianalisis dengan rumus berikut.

$$
\begin{aligned}
& \text { Persentase nilai }=\frac{\text { skor perolehan }}{\text { skor } \text { maksimum }} \times 100 \% \\
& \text { Dengan kriteria } \\
& 80 \%<\mathrm{x} \leq 100 \% \text { : sangat paham } \\
& 60 \%<x \leq 80 \% \quad \text { : Paham } \\
& 40 \%<\mathrm{x} \leq 60 \% \quad \text { : cukup paham } \\
& 20 \%<\mathrm{x} \leq 40 \% \quad \text { : kurang paham } \\
& \mathrm{X} \leq 20 \% \quad \text { :tidak paham } \\
& \text { (Widoyoko, 2016) }
\end{aligned}
$$

Nilai yang diperoleh dikelompokkan secara klasikal untuk nilai siswa dari tiap dimensi dan akan disimpulkan berdasarkan kriteria tersebut.

\section{HASIL DAN PEMBAHASAN}

Media audio visual yang berupa video ini berdurasi 7 menit 30 detik terdiri atas penayangan video dengan ringkasan isi. pembuka, isi dan penutup. Pembuka video ini menceritakan tentang keanekaragaman Hayati Indonesia baik keanekaragaman hayati flora maupun fauna yang berada di darat dan di air. Video pembuka ini mengadopsi dari video yang ada di youtube disesuaikan (diedit) baik gambar maupun suara yang digunakan agar tidak selaras dengan video yang di buat dari proses eksperimen DNA.

Bagian isi menjelaskan terlebih dahulu tentang Keanekaragaman Hayati sesuai pada tingkatannya. Keanekaragaman tingkat ekosistem dan contohnya Keanekaragaman ekosistem darat dan perairan, Keanekaragaman Spesies beserta contohnya. Keanekaragaman pada spesies Flora dan fauna dan keanekaragaman tingkat gen beserta contoh dari beberapa flora dan fauna. Bagian ini tidak hanya menampilkan konsep awal materi keanekaragaman, dilengkapi juga dengan gambar yang dibuat menggunakan power point dengan animasi dan suara baik berupa penjelasan maupun musik. Materi Kenekaragaman Gen yang ditampilkan mengantarkan ke video proses bagaimana langkah mengetahui keanekaragaman DNA. 


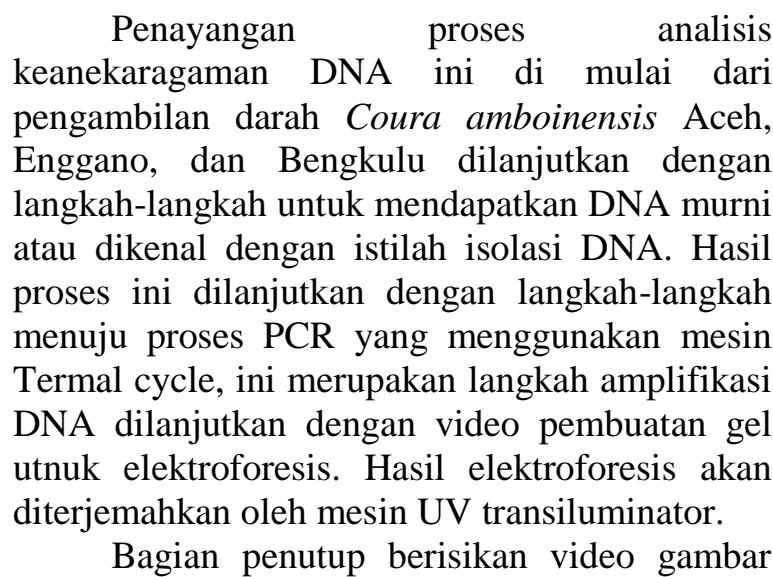
hasil UV transiluminator yang akan siap disekuensing, serta ucapan terimakasih pada semua pihak yang terlibat dalam peneitian.

Lembar diskusi dikerjakan setelah proses penayangan media video . Soal lembar diskusi siswa ini mengacu pada dimensi pemahaman menurut Anderson (2015) yaitu kemampuan menafsirkan, kemampuan menjelaskan, kemampuan mengklasifikasikan. Kemampuan menyimpulkan. Kemampuan menafsirkan dapat terlihat jika siswa dapat mengubah informasi dari satu bentuk ke bentuk yang lain. Pada lembar diskusi ini siswa diminta untuk menjelaskan pengertian dari keanekaragaan hayati berdaskan video yang menceritakan tentang keanekaragaman yang ada di alam yang ditayangkan sebelum pembelajaran. Pada butir soal ini nilai maksimal ada skor sepuluh sedangkan dari sebelas kelompok siswa memperoleh nilai rata-rata klasikal sembilan pada butir soal ini atau $86 \%$ siswa bisa menjawab. Jadi pada siswa telah memiliki kemampuan mengubah suatu informasi dari bentuk representasi yang satu ke dalam bentuk representasi yang lain. Pada soal ini informasi dari bentuk gambar /non-verbal ke dalam bentuk uraian kata-kata atau kalimat/ verbal (Anderson, 2014). Berdasarkan hasil ini telah menunjukkan bahwa media video ajar telah berhasil merangsang siswa agar lebih mudah memahami materi keanekaragaman genetik khususnya pada dimensi menafsirkan.

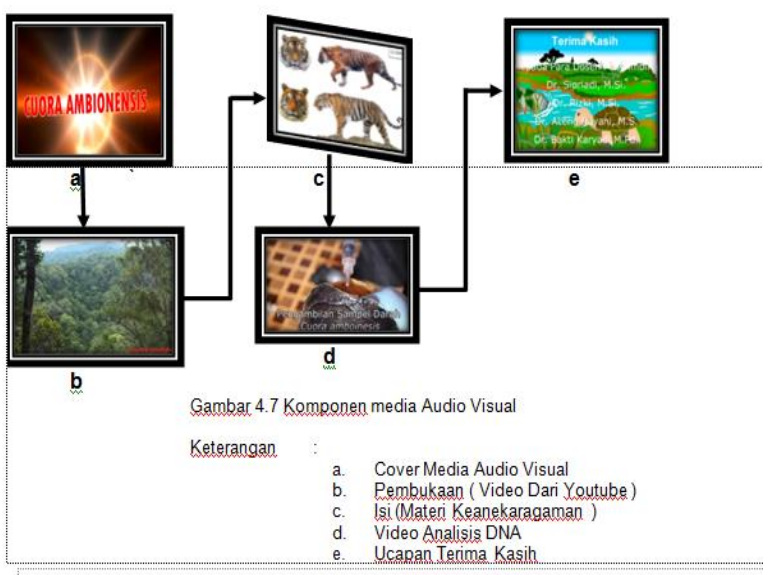

Gambar 1. Komponen media audio visual.

Kemampuan menjelaskan terdapat pada butir soal ke dua dan ke empat, pada butir ini siswa diharapkan dapat menalar untuk merangkai suatu alasan dari peristiwa yang merupakan sebab akibat seperti pada soal nomor dua yaitu menjelaskan gen menjadi penentu keanekaragaman hayati dan skor maksimal lima sedangkan dari analisis butir soal ini rata-rata nilai yang diperoleh telah menunjukkan siswa mampu untuk menjelaskan dengan baik dan soal nomor empat menjelaskan pengaruh geografi terhadap keanekaragaman hayati. Pada butir soal ini skor maksimal dan analisis butir soal rata-rata kelompok memperoleh nilai lima capaian nilai ini mendekati skor maksimal maka dari kedua soal ini rata-rata nilai secara klasikal skor lima atau $77 \%$ siswa bisa menjawab. Azhar (2004) mengatakan bahwa media adalah segala sesuatu yang dapat digunakan untuk merangsang pikiran, perasaan, perhatian dan kemajuan pembelajar sehingga dapat mendorong terjadinya proses belajar pada diri pembelajar. Jadi media ajar telah mendukung kegiatan belajar mengajar sehingga siswa lebih fokus baik pikiran, perasaan, dan perhatian sehinga mampu menjelaskan jawaban dari lembar diskusi yang di berikan secara langsung siswa telah mampu menguasai dimensi pemahaman yaitu menjelaskan.

Kemampuan mengklasifikasikan terjadi ketika siswa mengetahui bahwa sesuatu contoh termasuk dalam kategori tertentu (konsep atau prinsip) sehingga melibatkan proses untuk mendeteksi ciri-ciri atau pola-pola yang sesuai dengan konsep atau prinsip tersebut (Anderson, 2014). Pada butir soal ini siswa memperoleh niai 
lebih kecil dibandingkan pada dimensi lainnya hal ini dikarenakan pada butir mengklasifikasikan dimulai dari contoh tertentu dan mengharuskan siswa menemukan konsep atau prinsip dengan mendeteksi ciri-ciri baik dari contoh atau konsep umum sehingga siswa sedikit kesulitan hal ini terlihat dari hasil yaitu skor maksimal tujuh rata-rata klasikal yang diperoleh siswa dengan skor lima atau $66 \%$ dari siswa bisa menjawab. Media video merupakan stimulus yang akan membantu pembelajar mempelajari bahan pelajaran atau media pembelajaran seperti suara, visual dan gerakan, hal ini juga dapat menumbuhkan sikap, perbuatan mengorganisasi dan memanajemen yang berhubungan dengan penerapan ilmu, (Azhar, 2004). Jadi dapat disimpulkan media video juga mendukung siswa untuk dapat mengklasifikasikan mengorganisasikan materi pelajaran yang telah dipelajari sehingga dapat memahami materi dengan mudah.

Kemampuan menyimpulkan dapat dilakukan oleh siswa bilamana siswa tersebut telah dapat mengabstraksi suatu konsep atau prinsip. Pada tahap proses menyimpulkan siswa harus memiliki bekal kemampuan dalam membandingkan suatu contoh yang satu dengan contoh yang lain Proses menyimpulkan melibatkan proses kognitif membandingkan seluruh contoh, berpusat pada penarikan pola informasi yang disuguhkan (Anderson dan Krathwohl, 2014). Pada butir soal ini siswa membandingkan pengertian dari keanekaragaman hayati pada tingkat gen sedangkan tingkat lainnya keanekaragaman tingkat spesies dan ekosistem. Pada butir soal ini skor maksimal tujuh sedangkan rata-rata perolehan nilai yang diperoleh siswa secara klasikal memperoleh nilai dengan skor 6 atau $80 \%$ siswa mampu menjawab lembar diskusi pada soal ini. Media video pembelajaran ini ternyata dapat meningkatkan dan mengarahkan perhatian siswa sehingga dapat menimbulkan motivasi belajar, interaksi yang lebih langsung antara siswa dan lingkungannya dan kemungkinan siswa untuk belajar sendiri dengan demikian akan lebih mudah bagi siswa untuk menyimpulkan materi pembelajaran, hal ini juga akan mempercepat tingkat pemahaman siswa. Hasil yang diperoleh siswa dapat dilihat pada grafik berikut:

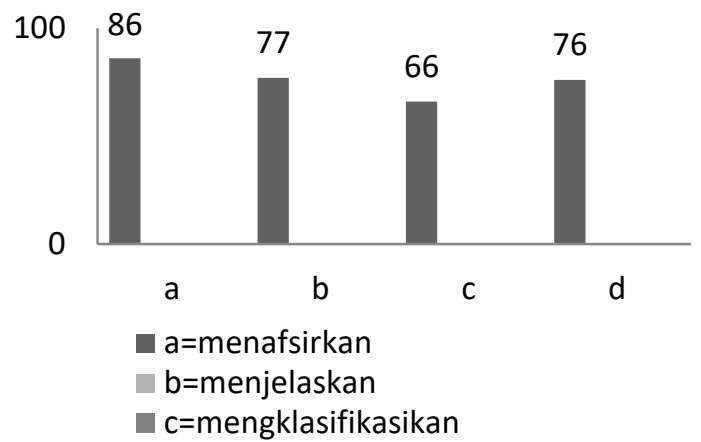

Gambar 2. Grafik Nilai Siswa

Hasil lembar diskusi ini jika dikelompokkan dalam teori Bloom yaitu siswa telah memiliki kemampuan pemahaman dalam menterjemahkan (translation) hal ini ditunjukkan pada soal dua dan empat mengenai siswa yang telah mampu menjelaskan dengan bahasanya sendiri tentang gen yang menjadi penentu keanekaragaman dan pengaruh letak geografi terhadap keanekaragaman genetik dengan persentase rata-rata kelas $77 \%$ terkatagori kelompok paham. Kemampuan pemahaman menafsirkan (interpretation) pada soal lembar diskusi terdapat pada butir soal satu dan lima yaitu siswa telah mampu menafsirkan pengertian keanekaragaman hayati dan keanekaragaman genetik dengan persentase nilai rata-rata kelas 83\% terkategori sangat paham, sedangkan pada tingkat kemampuan pemahaman menunjukkan (extrapolation) tertuang pada soal nomor tiga yaitu mengidentifikasi keanekaragaman gen pada contoh kelinci dan menentukan langkahlangkahnya dengan persentase yang diperoleh rata-rata kelas $66 \%$ terkategori paham.

Berdasarkan pembahasan di atas, dapat disimpukan bahwa dalam pemilihan media pembelajaran, dapat membantu seorang guru dalam menyampaikan pesan bisa lebih jelas dan mudah dipahami oleh siswa. Sriyanto (2010) mengatakan bahwa media adalah segala alat fisik yang menyajikan pesan serta merangsang siswa untuk belajar seperti film, buku dan kaset. Selain itu media pembelajaran dapat membangkitkan motivasi dan minat belajar yang baru dalam diri siswa. Salah satu media yang dapat digunakan dalam pembelajaran adalah meda audio visual. Media ini mempunyai kemampuan yang lebih, karena media ini mengandalkan dua indera sekaligus, yaitu indera pendengaran dan indera 
penglihatan. Media diharapkan bisa membangkitkan motivasi dalam belajar dan memperjelas materi yang disampaikan. Adapun kelebihan dari media audio visual menurut Supriatna (2009) adalah: Tepat untuk menerangkan suatu proses; Dapat menyajikan suatu teori ataupun praktek dari yang bersifat khusus ke umum atau sebaliknya; Lebih realistis dimana hal-hal yang bersifat abstrak menjadi terlihat lebih jelas; Merangsang motivasi peserta didik; Menghemat waktu karena dapat di putar ulang; Dapat mengamati lebih dekat objek yang berbahaya dan yang bergerak.

Hal ini sangat sesuai dengan teori belajar Peaget yaitu melalui pertukaran ide-ide dengan orang lain, seorang anak yang tadinya memiliki pandangan subyektif terhadap sesuatu yang diamatinya akan berubah pandangannya menjadi obyektif. Aktivitas mental anak terorganisasi dalam suatu struktur kegiatan mental atau pola tingkah laku (Peaget, 2010 ).

Berdasarkan uraian di atas, maka masalah dalam penelitian ini yaitu sulitnya materi keanekaragaman genetik dipahami oleh siswa telah teratasi dengan penggunaan media audio visual terlihat dari hasil belajar siswa mendapatkan skor yang memuaskan

\section{KESIMPULAN}

Media audio visual dari proses penelitian DNA Coura amboinensis dikembangkan menjadi media pembelajaran audio visual pada materi Keanekaragaman Hayati khususnya pada tingkat keanekaragaman genetik berisi video pengantar dari yutube, isi terdiri materi keanekaragaman diikuti proses analisis DNA dan penutup hasil dan penelitian sains dan ucapan terimakasih kepada semua pihak yang telah mendukung penelitian. Media pembelajaran telah tervalidasi dengan nilai yang layak untuk digunakan .

Media audio visual yang digunakan sebagai pedoman saat siswa mengerjakan Lembar Diskusi Siswa. Lembar diskusi siswa terdiri atas indicator pemahaman sehingga dapat mengukur kemampuan pemahaman siswa terhadap media audio visual yang ditampilkan. Hasil perolehan nilai siswa secara klasikal diatas $77 \%$ dengan kategori paham. Siswa mampu menjawab dengan benar lembar diskusi yang di gunakan berdasarkan media pembelajaran dan siswa lebih tertarik perhatian dan kosentrasinya terhadap pembelajaran sehingga semua dimensi pemahaman tercapai dengan nilai yang baik berarti siswa telah memahami materi keanekaragaman genetik.

\section{DAFTAR PUSTAKA}

Anderson, L, W dan Krathwohl, D, R. (2014). Pembelajaran,Pengajaran, dan Asesmen. Yogyakarta: Pustaka Pelajar.

Anderson, L, W dan Krathwohl, D, R. (2015). Pembelajaran,Pengajaran, dan Asesmen. Yogyakarta: Pustaka Pelajar.

Azhar, A. (2004). Media Pengajaran. Jakarta : PT Raja Grafindo Persada.

Iverson, J. B. (1992). A revised checklist with distribution maps of the turtles of the world (No. C/598.13 I9).

Math. (2017). Teori belajar Piaget-teori Perkembangan Kognitif. Ninamath.

Peaget, Bruner, Vygotsky. (2010). Teori-teori Belajar. Jakarta: PT.Rineka Cipta.: Privetely Printed, Richmond

Sriyanto.(2010) Pemanfaatan ICT Sebagai Media Pembelajaran.

Supriatna, D . (2009). PengEnalan Media Pembelajaran. Diklat E-Training PPPPTK TK dan PLB. Pusat Pengembangan Pendidik dan Tenaga Kependidikan Taman Kanak dan Luar Biasa.

Widoyoko, E, P. (2016). Evaluasi Program Pembelajaran. Yogyakarta: Pustaka Pelajar.

Winarni, E.W. (2012). Inovasi Dalam Pembelajaran IPA. FKIP UNIB. 